\title{
Existential-Humanistic Counseling Approach to Improve Self Management in Students
}

\author{
Fatma Sri Kumala Dewi ${ }^{1}$, Yarmis Syukur ${ }^{2}$ \\ ${ }^{12}$ Universitas Negeri Padang
}

\begin{tabular}{l} 
Article Info \\
\hline Article history: \\
Received Dec $14^{\text {th }}, 2019$ \\
Revised Jan $15^{\text {th }}, 2020$ \\
Accepted Feb $12^{\text {th }}, 2020$
\end{tabular}

\section{Keyword:}

Self-management

Existential-humanistic counseling

Student

\begin{abstract}
This article discusses students' self-management in managing and managing themselves related to time and the achievement of self-goals using a humanistic existential counseling approach. The study was conducted at one of the High Schools in the City of Padang. Which is done on one student. By using data collection techniques with interviews and observations. The results of this study are that the student knows what he wants and sets out what he will do, already knows clearly what goals he will achieve, understands the goals to be achieved by making plans to achieve what he wants
\end{abstract}

\section{Corresponding Author:}

Fatma Sri Kumala Dewi

Email: dewifatma29@gmail.com

\section{Pendahuluan}

Pendidikan merupakan kemampuan individu dalam perencanaan untuk mewujudkan suasana belajar dan proses pembelajaran agar peserta didik aktif dalam mengembangkan potensi dirinya untuk memiliki kekuatan spiritual keagamaan, kepribadian, pengendalian diri, kecerdasan, akhlak mulia, serta keterampilan yang diperlukan untuk dirinya dan masyarakat. Lembaga pendidikan formal berfungsi mendidik siswa melalui dua kegiatan yaitu proses pembelajaran (intra kurikuler) dan kegiatan organisasi (ekstra kurikuler). (Ihsani, 2013).

Proses pembelajaran yaitu kegiatan dari tidak tahu, tidak mengerti, tidak bisa menjadi tahu, mengerti dan bisa secara optimal. Belajar terbagi menjadi beberapa fase untuk mengerti tingkatan belajar anak dalam mengenali suatu hal yang harus dipelajari. Kegiatan organisasi mengikuti kegiatan yang ada di sekolah OSIS, pramuka, dll. Banyaknya kegiatan yang diikuti oleh peserta didik yaitu belajar dan beberapa kegiatan ekstrakulikuler, membutuhkan kemampuan dalam mengatur atau manajemen diri. Manajemen diri adalah bagaimana individu mengatur dan mengelola diri sendiri dalam hal yang berkaitan dengan pemenuhan kebutuhan, waktu dan pencapaian tujuan diri (Juana, 2000).

Menurut Prijosaksono (Satria, 2012), manajemen diri atau self management merupakan kemampuan individu untuk mengendalikan sepenuhnya keberadaan diri secara keseluruhan (fisik, emosi, mental atau pikiran, jiwa maupun rohnya) dan realita kehidupannya dengan memanfaatkan kemampuan yang dimilikinya. Manajemen diri dikemukakan oleh Suhartini (Suhartini, 1992) adalah suatu prosedur yang menuntut seseorang untuk mengarahkan atau mengatur tingkah lakunya sendiri. Sejalan dengan hal tersebut, 
Gie (Gie, 1996) berpendapat bahwa manajemen diri adalah segenap kegiatan dan langkah dalam mengatur dan mengelola dengan sebaik-baiknya sehingga mampu membawa ke arah tujuan hidup.

Mengatur dan mengelola mengenai apa yang diinginkan, mengetahui langkah-langkah apa yang akan diambil dan mengetahui nilai-nilai apa yang kita yakini, kearah mana perkembangan yang kita tuju, hal ini dikemukakan oleh Viktor Frankl dalam teorinya Humanistik mengenai keinginan untuk makna; kita memiliki kebebasan untuk menemukan makna dalam semua yang kita pikirkan; dan kita harus mengintegrasikan tubuh, pikiran, dan roh untuk menjadi hidup sepenuhnya (Corey, 2010)

Dalam pendekatan konseling, diantaranya ada pendekatan eksistensial-humanistik yang memandang manusia memiliki kesanggupan untuk menyadari dirinya sendiri, suatu kesanggupan yang unik dan nyata yang memungkinkan manusia mampu berpikir dan memutuskan sehingga mampu membuka diri dan bertindak sesuai kemampuannya (Corey, 2010).

Manusia memandang kemampuan dan keinginan untuk memilih dan membuat keputusan sendiri. Manusia memiliki unsur kemerdekaan atau kebebasan memilih dalam memandang, menjelajah, dan menantang alam dan dunia ditentukan berada disekelilingnya, Natawidjaja (Wijaya $\square, 2014$ ). Selanjutnya, Corey (Wijaya $\square$, 2014) menyatakan bahwa Konseling eksistensial humanistik adalah pendekatan yang memfokuskan pada keterbukaan dan keberadaan klien, membebaskan klien, membangun kesadaran diri, tanggung jawab klien, mengakui bahwa putusan-putusan dan pilihan-pilihan akhir terletak pada tangan klien, mengakui kebebasan klien untuk mengungkapkan pandangan dan untuk mengembangkan tujuan-tujuan dan nilai dirinya sendiri, bekerja kearah mengurangi kebergantungan klien serta meningkatkan kebebasan klien

Teori konseling Eksistensial Humanistik tidak memiliki teknik konseling yang ditentukan secara ketat. Hanya sedikit teknik yang dikembangkan oleh konseling Eksistensial Humanistik, sebab pendekatan ini mendahulukan pemahaman alih-alih teknik. Prosedur-prosedur konseling bisa diadopsi dari beberapa pendekatan yang lain, berfokus pada kondisi manusia, berlandaskan konsep-konsep dan asumsiasumsi tentang manusia (Singaraja et al., 2013)

Berdasarkan penjelasan diatas, bahwa bagaimana individu bebas memutuskan pilihan-pilihan dan mengembangkan tujuan dirinya sendiri yang terdapat dalam pengertian manajemen diri yaitu kemampuan individu untuk mengendalikan sepenuhnya keberadaan diri secara keseluruhan (fisik, emosi, mental atau pikiran, jiwa maupun rohnya) dan realita kehidupannya dengan memanfaatkan kemampuan yang dimilikinya (Satria, 2012). Tujuannya adalah untuk mengetahui sadar akan kemampuannya dirinya, mengetahui tujuan dan langkah ke depannya dan bertanggung atas setiap keputusan atau pilihan yang telah dibuatnya.

\section{Kajian teori \\ Pengertian Manajemen diri}

Menurut Prijosaksono (Satria, 2012), manajemen diri atau self management merupakan kemampuan individu untuk mengendalikan sepenuhnya keberadaan diri secara keseluruhan (fisik, emosi, mental atau pikiran, jiwa maupun rohnya) dan realita kehidupannya dengan memanfaatkan kemampuan yang dimilikinya.

Manajemen diri dikemukakan oleh Suhartini (Suhartini, 1992) adalah suatu prosedur yang menuntut seseorang untuk mengarahkan atau mengatur tingkah lakunya sendiri. Sejalan dengan hal tersebut, Gie (Gie, 1996) berpendapat bahwa manajemen diri adalah segenap kegiatan dan langkah dalam mengatur dan mengelola dengan sebaik-baiknya sehingga mampu membawa ke arah tujuan hidup.

Soekadji (Soekadji, 1983) mengemukakan manajemen diri adalah suatu prosedur yang menuntut seseorang untuk mengarahkan atau menata tingkah lakunya sendiri. Prosedur ini melibatkan subjek dalam beberapa tahap, yaitu a) menentukan sasaran tingkah laku yang hendak dicapai, tujuan yang sudah ditetapkan akan lebih mengarahkan seseorang pada bagaimana cara mencapai tujuan dan bagaimana ia menempatkan prioritas tugas yang diperlukan guna mencapai tujuan tersebut; $b$ ). memonitor tingkah lakunya dengan cara menentukan sendiri prosedur yang hendak dipakai untuk memonitor perkembangan yang sudah dicapai, bentuk aplikasi dari teknik ini antara lain dengan cara mencatat atau membuat grafik sehingga perubahan data dapat dilihat individu yang bersangkutan dan berfungsi sebagai insentif atau penguat (reinforcer); dan c) mengevaluasi perkembangan tingkah lakunya, dalam tahap ini, individu yang bersangkutan mengevaluasi kembali apa yang telah dikerjakannya, sudah sesuai dengan yang ditargetkan atau belum.

Manajemen diri atau self management merupakan kemampuan individu untuk mengendalikan sepenuhnya keberadaan diri secara keseluruhan (fisik, emosi, mental atau pikiran, jiwa maupun rohnya) dan realita kehidupannya dengan memanfaatkan kemampuan yang dimilikinya. Manajemen diri merupakan 
pengelolaan impuls dan perasaan yang menekan tergantung pada keselarasan kerja pusat emosi dan pusat eksekusi otak di lobus prefrontal. Berkaitan dengan hal tersebut di atas, O'Keefe dan Berger mendefiniskan self management sebagai menyelesaikan tujuan, melakukan hal seperti biasanya mengenai diri sendiri dengan kebebasan dan spontan (Prijosaksono, 2001)

\section{Aspek-aspek manajemen diri}

Aspek-aspek manajemen diri yang dikemukakan oleh Prayue (Rengginas, 2005), meliputi: a) mengenali diri secara menyeluruh. Didalam diri individu pasti sudah bisa mengerti atau menilai tentang dirinya sendiri, b). mengidentifikasi dengan jelas tujuan yang ingin dicapai, mengidentifikasi yang ada dalam individu tersebut bagaimana seseorang itu mempunyai rencana untuk menuju kearah sesuatu atau mengerah kepada suatu tujuan bahwa manusia pada hakekatnya ingin menuju kepada sesuatu, c) memahami pentingnya mencapai tujuan tersebut. Didalam diri individu yang ingin mewujudkan tujuannya pasti sudah mengerti apa pentingnya tujuan itu bagi dirinya sendiri. Mengontrol dan mengelola diri (tingkah laku dan emosi). Seseorang harus bisa memahami diri sendiri dengan sepenuhnya dengan cara yang terpenting yaitu bagaiamana dalam diri individu tersebut bias mengelola diri disaat emosi dan perbuatan/tingkah lakunya, e) melakukan evaluasi diri atas apa yang telah dilakukan dan memahami insentif-insentif yang akan diperoleh dari tindakan yang dilakukan

\section{Konseling Eksistensial Humanistik}

Konseling dengan pendekatan humanistik berfokus pada kondisi manusia. Pendekatan ini terutama adalah suatu sikap yang menekankan pada suatu pemahaman atas manusia. Manusia dipandang sebagai makhluk yang memiliki otoritas atas kehidupan dirinya dalam pandangan humanistik. Manusia bebas untuk menjadi apa dan siapa sesuai keinginannya. Manusia adalah makhluk hidup yang menentukan sendiri apa yang ingin dia lakukan dan apa yang tidak ingin dia lakukan, karena manusia adalah makhluk yang bertanggung jawab atas segala apa yang dilakukannya. Asumsi ini menunjukkan bahwa manusia adalah makhluk yang sadar, mandiri, aktif yang dapat menentukan (hampir) segalanya aktivitas kehidupannya. Manusia adalah makhluk dengan julukan "the self determining being" yang mampu sepenuhnya menentukan tujuan-tujuan yang paling diinginkannya dan cara-cara mencapai tujuan itu yang dianggapnya paling benar dan paling tepat tepat (Zulfikar, Hariko, Muwakhidah, \& Aritonang, 2017)

Konselor teori humanistik, termasuk Frankl, Bugental, Rogers, dan Maslow, penentuan nasib sendiri bagian berharga dari klien. Mereka menekankan pentingnya bahwa konselor menemukan potensi pada kliennya yang unik. Mereka percaya pada pentingnya memfasilitasi klien untuk memahami diri mereka sendiri berkenaan dengan potensi yang unik ini dari diri mereka. Misalnya, dengan mendorong klien untuk melihat ke dalam dan untuk menjelajah ke wilayah yang tidak dikenal dalam rangka menyadari potensi yang belum dimanfaatkannya. (Zulfikar et al., 2017)

Artinya apapun keputusan yang diambil oleh klien konselor wajib menghargai setiap keputusannya itu, karna pada prinsipnya segala keputusan yang diambil oleh klien adalah tanggung jawabnya. Dialah yang akan menjalani setiap keputusan yang telah diambilnya. Namun konselor disini tetap memberikan arahan pada potensi yang dimiliki oleh klien yang barangkali potensi yang dimilikinya itu tidak disadari. (Zulfikar et al., 2017)

\section{Proses Konseling Humanistik}

Dalam pendekatan eksistensial humanistic, tidak memiliki penggunaan teknik yang ditentukan secara ketat dan proses terapi bisa diambil dari beberapa pendekatan terapi lainnya. Metode-metode yang berasal dari terapi Gestah dan Analisis Transaksional sering digunakan, dan sejumlah prinsip dan prosedur psikoanalisis bisa diintegrasikan ke dalam pendekatan eksistensial humanistic (Corey, 2010)

\section{Tujuan Konseling Humanistik}

Menurut Corey (Corey, 2010) ada beberapa tujuan konseling Eksistensial humanistik yaitu: (1) agar klien menyadari keberadaannya secara otentik dengan menjadi sadar atas keberadaan dan potensi-potensinya serta sadar bahwa ia dapat membuka diri dan bertindak berdasarkan kemampuannya. Keotentikan adalah sebagai "urusan utama psikoterapi" dan "nilai eksistensial pokok". Karakteristik dari keberadaan otentik yaitu menyadari sepenuhnya keadaan sekarang, memilih bagaimana hidup pada saat sekarang, memikul tanggung jawab untuk memilih; (2) meluaskan kesadaran diri klien, dan karenanya meningkatkan kesanggupan pilihannya yakni menjadi bebas dan bertanggung jawab atas arah hidupnya; (3) membantu klien agar mampu menghadapi kecemasan sehubungan dengan tindakan memilih diri, dan menerima kenyataan bahwa dirinya lebih dari sekadar korban kekuatan-kekuatan deterministic di luar dirinya. 


\section{Metode Penelitian}

Artikel ini termasuk pendekatan kualitatif dengan jenis studi kasus. Penelitian studi kasus adalah penelitian yang bertujuan mengembangkan analisis secara mendalam dari sebuah kasus tunggal atau kasus jamak (Creswell, 2007). Studi kasus mengutamakan eksplorasi dari suatu sistem yang saling terkait satu sama lain dalam beberapa hal satu kasus secara mendetail, disertai dengan penggalian data secara mendalam yang melibatkan dari berbagai lini yang kaya akan konteks (Herdiansyah, 2015). Peneliti dalam kualitatif bertindak sebagai instrumen penelitian yang memberikan gambaran tentang kondisi secara faktual dan sistematis fenomena yang dimiliki (Moleong, 2007).

Teknik pengambilan data melalui wawancara dan observasi. Responden dalam penelitian merupakan seorang peserta didik yang sedang bersekolah di SMA di Kota Padang. Adapun analisis data dengan mengikuti reduksi data, penyajian data, dan kesimpulan.

\section{Hasil dan pembahasan Temuan penelitian}

Temuan penelitian ini mendeskripsikan tentang aspek-aspek manajemen diri dengan pendekatan konseling eksistensial-humanistik. Penelitian ini mengungkap manajemen diri peserta didik berjenis kelamin laki-laki berinisial BNP, yang terdiri dari: 1) Mengenali diri secara menyeluruh, 2) Mengidentifikasi dengan jelas tujuan yang ingin dicapai, 3) Memahami pentingnya mencapai tujuan tersebut, 4) Mengontrol dan mengelola diri (tingkah laku dan emosi), 5) Melakukan evaluasi diri atas apa yang telah dilakukan dan memahami insentif-insentif yang akan diperoleh dari tindakan yang dilakukan.

BNP merupakan anak kedua dari dua bersaudara. Lahir pada tahun 2002, dan berdomisili di Padang. Ayah BNP bekerja sebagai wiraswasta dan ibunya sebagai ibu rumah tangga. BNP mengikuti kegiatan organisasi tahun lalu dan dapat membagi waktu belajar dengan organisasi. Tahun 2019 ini BNP ingin fokus belajar dan ingin mengikuti cita-citanya kuliah di tempat favoritnya, dengan membagi waktu belajarnya dan waktu bermain dengan teman-temannya.

Perolehan data yang didapatkan oleh peneliti beberapa kali melalui pendekatan eksistensial-humanistik. Konseling dilakukan baik di ruang konseling mauapun di halaman sekolah. Kemudian peneliti senantiasa membangun raport dengan klien (BNP) dengan menumbuhkan rasa nyaman dan akrab agar klien terbuka dalam mengemukakan masalahnya.

\section{Mengenali diri secara menyeluruh}

Didalam diri individu sudah bisa mengerti atau menilai tentang dirinya sendiri. Mengenali diri sendiri agar lebih mudah dalam merubah apa yang ingin dirubah dalam diri sendiri.

Dari hasil konseling dan observasi yang dilakukan kepada BNP, BNP sudah menyadari dan mengetahui apa yang diinginkannya dengan memutuskan bahwa pada tahun sekarang BNP ingin fokus belajar dan mengejar cita-citanya untuk kuliah di tempat yang diinginkannya dan juga pengalaman berorganisasi sudah di rasakannya pada tahun lalu, jadi BNP tidak ikut bergabung dalam kegiatan organisasi lagi.

\section{Mengidentifikasi dengan jelas tujuan yang ingin dicapai}

Mengidentifikasi yang ada dalam individu tersebut bagaimana seseorang itu mempunyai rencana untuk menuju kearah sesuatu atau mengarah kepada suatu tujuan bahwa manusia pada hakekatnya ingin menuju kepada sesuatu.

Tujuan yang diinginkan oleh BNP adalah ingin mendapatkan kampus yang diinginkannya, dengan fokus belajar di tahun sekarang, membagi waktu di rumah antara belajar dan waktu bermain.

\section{Memahami pentingnya mencapai tujuan tersebut}

Didalam diri individu yang ingin mewujudkan tujuannya pasti sudah mengerti apa pentingnya tujuan itu bagi dirinya sendiri.

BNP mengetahui bahwa dari fokus belajar pada tahun sekarang untuk mendapatkan kampus diinginkannya, mecoba mencari kesempatan bagaimana mendapatkan kampus itu dengan mencari informasiinformasi mengenai jurusan dan kampus serta berusaha fokus ketika belajar 


\section{Mengontrol dan mengelola diri (tingkah laku dan emosi)}

Seseorang harus bisa memahami diri sendiri dengan sepenuhnya dengan cara yang terpenting yaitu bagaimana dalam diri individu tersebut bisa mengelola diri disaat emosi dan perbuatan/tingkah lakunya.

BNP berusaha mengikuti semua peraturan yang ada di sekolah dan menjalin hubungan yang baik antar teman dan gurunya sehingga menjaga emosi dan sikap BNP serta tidak mengganggu kepada yang diinginkannya. BNP sadar jika melanggar peraturan yang ada di sekolah akan mengganggu konsentrasi belajarnya dan akan menambah pikiran yang lain selain dari tujuan dari masa depannya tetapi kadang-kadang BNP ada juga ikut meribut di kelas, dan tidak memperhatikan guru ketika pelajaran yang tidak disukainya.

\section{Melakukan evaluasi diri atas apa yang telah dilakukan dan memahami insentif-insentif yang akan diperoleh} dari tindakan yang dilakukan.

Individu yang bersangkutan mengevaluasi perkembangan dari rencana kerjanya, apakah targetnya tercapai, apakah batas waktunya terpenuhi, apakah konsekuensi yang diperoleh setelah tercapainya target yang sudah ditetapkan itu.

BNP kadang melakukan pengecekan pada nilai harian yang didapat, dan mempelajari kembali jawaban yang kurang tepat pada pertanyaan yang diberikan, menanyakan kepada guru mengenai soal-soal yang kurang paham atau berdiskusi dengan teman yang lebih dari dia

\section{Simpulan}

Hasil penelitian terungkap bahwa manajemen diri peserta didik sebagai berikut: (1) BNP mengtahui apa yang diinginkannya dan menetapakan apa yang akan dilakukannya; (2) BNP sudah mengetahui dengan jelas tujuan apa yang akan dicapainya; (3) BNP memahami tujuan yang akan dicapai dengan membuat rencanarencana untuk mencapai yang diinginkannya; (4) BNP berusaha mematuhi semua peraturan di sekolah meskipun kadang ada juga ikut meribut di kelas dan tidak memperhatikan pelajaran yang tidak disukainya; (5) BNP melakukan beberapa pengecekan jawaban yang kurang tepat dan berdiskusi dengan guru dan teman yang lebih paham mengenai hal-hal yang kurang paham bagi BNP. Jadi, dapat disimpulkan bahwa BNP memiliki manajemen diri yang baik.

\section{Ucapan terima kasih}

Peneliti mengucapkan terima kasih kepada bapak Amriman M, S. Pd., M. M selaku kepala sekolah yang memberikan kesempatan untuk meneliti di tempat beliau. Terima kasih juga penulis ucapkan kepada Ibu Sirnayetti, S. Pd., Kons selaku guru BK di sekolah tersebut. Terima kasih juga penulis ucapkan kepada keluarga yang selalu mendukung dan mendoakan. Selanjutnya teman-teman sejawat yang senantiasa memberikan kritik dan sarannya dalam proses penelitian ini. Semoga ini bisa memberi manfaat bagi banyak orang terkhusus di lingkup BK.

\section{Daftar Pustaka}

Corey, G. (2010). Teori dan Praktek Konseling dan Psikoterapi. Bandung: Refika Aditama.

Creswell, J. W. (2007). Research Design (Second Edi). London and New delhi: Sage Publication.

Gie, T. L. (1996). Strategi Hidup Sukses. Jogjakkarta: Liberty.

Herdiansyah, H. (2015). Metodologi Penelitian Kualitatif untuk Ilmu Psikologi. (Rosidah, Ed.) (1st ed.). Jakarta: Salemba Humanika.

Ihsani, F. (2013). Hubungan Antara Siswa Mengikuti Organisasi Siswa Intra Sekolah Dan Kedisiplinan Belajar Dengan Prestasi Belajar Sosiologi Siswa Kelas X SMA Negeri 6 Surakarta Tahun Pelajaran 2012/2013, (2).

Juana. (2000). Kesesuaian antara Konsep Diri Nyata dan Ideal dengan Kemampuan Manajemen Diri pada Mahasiswa Pelaku Organisasi. Jurnal Psikologika, 9(5), 65-76.

Moleong, L. . (2007). Metodologi Penelitian Kualitatif (23rd ed.). Bandung: PT. Remaja Rosdakarya.

Prijosaksono, A. (2001). Self Mangement Series. Jakarta: Gramedia.

Rengginas. (2005). Peran Manajamen Diri dan Kematangan Emosi dengan Pengambilan Keputusan. UGM. 
Satria, H. (2012). Hubungan Antara Manajemen Diri Dengan Motivasi Berwirausaha Pada Siswa SMK. Naskah Publikasi.

Singaraja, S. M. P. N., Ayu, I., Nanda, S., Dantes, N., Nengah, N., \& Antari, M. (2013). Pengaruh Implementasi Konseling Eksistensial Humanistik Dengan Teknik Modeling Untuk Meningkatkan SelfEsteem Siswa Teraliensi Di Kelas VIII SMP Negeri 6 Singaraja.

Soekadji, S. (1983). Modifikasi Perilaku Penerapan Sehari-hari dan Penerapan Profesional. Yogyakarta: liberty Walker.

Suhartini, H. (1992). Pengaruh Metode Pengelolaan Diri Sendiri Terhadap Prestasi Kerja Praktek Harian. Jurnal Psikologi, 1, 25-30.

Wijaya $\square$, R. S. (2014). Model Konseling Kelompok Eksistensial Humanistik Uuntuk Mengurangi Kecemasan Siswa Menentukan Arah Peminatan SMA Negeri Semarang. Jurnal Bimbingan Konseling, 3(2).

Zulfikar, Hariko, R., Muwakhidah, \& Aritonang, N. (2017). Konseling Humanistik: Sebuah Tinjauan Filosofi. Jurnal Konseling GUSJIGANG, 3(1). 